\title{
Uwagi o współczesnych przekładach Biblii na język polski
}

1. Na rynku wydawniczym ukazują się publikacje przedstawiane czytelnikom jako przekłady Pisma Świętego na gwary i regionalne lub środowiskowe odmiany języka. Są to na przykład: Biblia Ślązoka Marka Szołtyska ${ }^{1}$, Ewangelie, a następnie cały Nowy Testament w gwarze podhalańskiej², wreszcie Dobra Czytanka wg św. ziom'a Janka3. Zazwyczaj nie towarzyszy im żaden komentarz, poza informacyjno-marketingowym.

2. Przede wszystkim pragniemy zwrócić uwagę na pewne nadużycia terminologiczne: zgodnie z zaleceniami Soboru Watykańskiego II za przekład Biblii należy uważać tekst tłumaczony bezpośrednio ,z biblijnych języków oryginalnych”. Wyjaśniając, należy powiedzieć, że chodzi o tekst Biblii, który w przypadku Starego Testamentu powstał w języku hebrajskim i aramejskim (tzw. księgi protokanoniczne) bądź greckim (tzw. księgi deuterokanoniczne), a w przypadku Nowego Testamentu - tylko w języku greckim. Jedynie te teksty uznawane są bowiem za natchnione (zob. Sobór Watykański II, konst. Dei Verbum, 22). Ostatnio tę soborową zasadę przypomniała Kongregacja Kultu Bożego i Dyscypliny Sakramen-

\footnotetext{
${ }^{1}$ Marek Szołtysek, Biblia Ślazoka, Rybnik 2000.

${ }^{2}$ Ewangelie w przekładzie Marii Matejowej Torbiarz na gwarę górali skalnopodhalańskich $z$ Zakopanego. Praca studyjna na podstawie Biblii Tysiąclecia, Wydawnictwo Pallottinum 1982, Poznań-Zakopane Krzeptówki 2002. 30 stycznia 2005 dokonano w Sanktuarium Matki Bożej Fatimskiej w Zakopanem oficjalnej prezentacji drugiej części Nowego Testamentu (Dzieje Apostolskie, Listy, Apokalipsa), którego pierwszy egzemplarz wręczono Ojcu Świętemu Janowi Pawłowi II 15 grudnia 2004 podczas przekazywania choinek z Podhala (http: //www.watra.pl/kosciol/sanktuarium/2005styczen/biblia.html). Całość NT ukazała się w roku 2005 jako Nowy Testament w przekładzie Marii Matejowej Torbiarz na gwarę górali skalnopodhalańskich z Zakopanego. Praca studyjna na podstawie Biblii Tysiąclecia Wydawnictwo Pallottinum 1982, Poznań-Zakopane Krzeptówki 2005.

${ }^{3}$ Fragmenty Ewangelii według św. Jana (rozdziały 3 i 4) w języku slangowym zostały opublikowane na stronie http://ziomjanek.pl, cytowano je również w prasie: Koło, I Bóg kazat rymować, „Polityka” 52-53 (2484), 25 grudnia 2004 - 1 stycznia 2005.
} 
tów w instrukcji Liturgiam authenticam z 2001 roku: „w żadnym wypadku nie wolno dokonywać przekładów z tłumaczeń opracowanych już na inne języki, [...] należy tłumaczyć bezpośrednio z tekstów oryginalnych” (p. 24). Tymczasem wspomniane publikacje opierają się niemal wyłącznie na Biblii Tysiąclecia (lub innych polskich przekładach) ${ }^{4}$.

3. Problematyczna wydaje się w ogóle celowość „,przekładów” (trawestacji, adaptacji) na gwary i języki o ograniczonym zasięgu społecznym. Zatwierdzone przez władze kościelne i uznane przez opinię filologów, używane w liturgii i nauczaniu przekłady biblijne na polski język literacki, mimo własnej specyfiki stylowej, nie są wszak tak niezrozumiałe, aby stwarzały konieczność dodatkowego tłumaczenia na jakikolwiek język rzekomo bardziej przystępny. Zwłaszcza że stuprocentowa zrozumiałość dla określonego wąskiego środowiska nie jest ani nie może być wystarczajaccym powodem tworzenia nowego przekładu Pisma Świętego. Zasadą jest tutaj stylistyczna, treściowa i emocjonalna wierność tekstowi oryginalnemu. A zwyczajnym miejscem wyjaśniania słowa Biblii i rodzenia się słowa Bożego jest przestrzeń liturgii oraz wprowadzająca w tę przestrzeń katecheza. Ponadto tekst Biblii ma nie tylko cel komunikacyjny, ale także cel wychowawczy: uwrażliwienia na świat wartości i na przeżycie religijne, czemu towarzyszy artystyczny, literacki i - ogólnie mówiąc - „wysoki” styl języka. Poszukiwanie takiego wzorca stylowego winno się dokonywać nie poprzez zabiegi głębokiej archaizacji i odwoływanie się do form i konstrukcji martwych. Nie oznacza to także kurczowego trzymania się reliktów języka i sytuowania Biblii w szeregu szacownych zabytków przeszłości. Idzie raczej o umiejętny wybór tych cech tradycyjnego stylu biblijnego, które nie zaciemniają tekstu, lecz nadają mu pożądane dostojeństwo, tak żeby wierny miał poczucie spotkania z językiem innym niż otaczający go na co dzień (reklama, polityka, media).

${ }^{4} \mathrm{~W}$ niniejszym wystąpieniu nie zajmujemy się kaszubskimi tłumaczeniami Biblii. Po pierwsze, istniała kaszubska religijna tradycja literacka, którą można datować od XVI w. (Duchowne piesnie z roku 1586). XX-wieczne poczynania translatorskie były znacznie dojrzalsze niż omawiane przez nas. Są to: Kaszëbskô Biblëjô. Nowi Testament. IV Ewanjelje. Z łacëznë przełożëł na kaszëbsczi jãzëk ks. Franciszek Grucza, Poznań 1992; Swięté Pismiona Nowégo Testameńtu. Na podstawie Biblii Tysiąclecia [...] skaszëbił Eugeniusz Gołąbek, Gdańsk-Pelplin 1993, tegoż tłumacza Knéga Psalmów, Gdańsk 1999, wreszcie Ewanielëjô wedle swiãtegò Marka z greczi przełożił na kaszëbsczi jãzëk ò. Adam Ryszard Sikora OFM, Gdańsk-Nałęczów-Poznań 2001. Ostatni przekład w pełni zasługuję na tę nazwę, dokonany został przez biblistę, z oryginału, opiniowany przez specjalistów, aprobowany przez władze kościelne - zob. A. R. Sikora, Kaszubskie przekłady Pisma Świętego, , Ruch Biblijny i Liturgiczny" 4 (2004), s. 301-304. Ponadto zmieniał się status kaszubszczyzny. Ustawa z dnia 6 stycznia 2005 r. o mniejszościach narodowych i etnicznych oraz o języku regionalnym stanowi, że język kaszubski jest językiem regionalnym (art. 19). 
Próby idące w kierunku oddania Pisma Świętego w języku lokalnym lub środowiskowym niosą niebezpieczeństwo swego rodzaju „prywatyzacji” tego, co powszechne i wypracowane w drodze długiej tradycji przekładowej i egzegetycznej. Co więcej, skazują owe inicjatywy na niemal pewną porażkę wszędzie tam, gdzie owe odmiany językowe nie dysponują odpowiednim potencjałem form i gatunków wypowiedzi, jakie niesie tekst biblijny, obfitujący nieprzebranym bogactwem symboli, obrazów i rodzajów literackich właściwych językom biblijnym (hebrajski, aramejski, grecki). Tym trudnym wyzwaniom może sprostać język etniczny o określonym stopniu „wyrobienia” literackiego pod piórem równie sprawnego i wszechstronnie przygotowanego thumacza (thumaczy). W tych trudnych decyzjach bibliście winien przyjść z pomocą filolog, aby najważniejsza płaszczyzna i sakralna funkcja słowa nie została zubożona lub zatracona w wyniku błędnych wyborów językowych.

Niezależnie od powyższych spostrzeżeń należy zwrócić uwagę na fakt, że istnieją przecież wydania całej Biblii i poszczególnych jej ksiąg z komentarzami przeznaczone dla różnego rodzaju odbiorców: na przykład Biblia Tysiąclecia, Biblia warszawsko-praska, Biblia Towarzystwa Biblijnego (przeznaczone dla ogółu odbiorców); Biblia poznańska (kilkutomowa, przeznaczona dla odbiorcy poszukującego wyjaśnień bardziej szczegółowych) itd.

4. Pojawiające się obecnie próby trawestacji tekstów biblijnych (już istniejących w języku polskim) na gwary i slang budzą nasze głębokie zaniepokojenie, i to zarówno na płaszczyźnie teologiczno-religijnej, jak i na płaszczyźnie językoznawczo-filologicznej. Poniżej przedstawiamy kilka przykładów, które ilustrują liczne problemy, uchybienia, anachronizmy i błędy znajdujące się w omawianych tekstach.

Biblia Ślazoka to raczej „,historie biblijne”, ,przetłumaczone” (strawestowane) na dialekt śląski, połączone z eksplikacją poglądów autora na historię i współczesność Górnego Śląska. Razi tam zwłaszcza niezgodność z treścią Pisma Świętego, nieuzasadniona poufałość wyrażana zdrabnianiem imion i teologiczna beztroska „tłumacza”. Na przykład: Ponboczek to zarówno Bóg Ojciec, jak i Jezus: „Ponboczek kozoł ci pedzieć, że poczniesz i urodzisz synka [...] o kerym bydom godać, że je Ponboczkowym Synkiym” (zwiastowanie, por. Łk 1,31-32, s. 46); „Ponboczek uros na fajnego karlusa [to tekst niebiblijny]. Ale w jedna noc zaś przyśnioł sie Zefkowi anioł...” (ucieczka do Egiptu, por. Mt 2,13).

We wszystkich omawianych tekstach rażą niestosowne i anachroniczne gwarowe ekwiwalenty realiów i wyrażeń biblijnych. Gwarowe i środowiskowe odpowiedniki utrwalonych w pamięci zbiorowej polskich tłumaczeń słów z Biblii nie niosą tych samych skojarzeń. Nieodpowiednie nawet z punktu widzenia „wewnątrzgwarowego” jest góralskie „Kawalerze, godom ci - wstoń!” 
(Łk 7,14) zamiast „chłopce”, ponieważ „kawaler” to „,zalotnik, narzeczony”, czy śląskie, trochę lekceważące „frelka” („dziewczyna”) w odniesieniu do Maryi i „nojszykowniyjszo” („najładniejsza, najzgrabniejsza”) w znaczeniu „błogosławiona” (Łk 1, 28). W „góralskim” Nowym Testamencie występują również nieuzasadnione innowacje ortograficzne, np. „bes” („bez”), „,zmortwykfstanie” (,zmartwychwstanie”), „ftos” zamiast „ftoz” („któż”), niekonsekwencje: „ukrzyżowanie” obok „ukrzizowali”; składnia zaś niewolniczo podąża za Biblią Tysiąclecia. Podobnie młodzieżowe: „Zaproszono też na tę imprę Jezusa i jego uczniów. Jak zabrakło im wina, matka Jezusa zagadała do niego: poszło całe wino” (wesele w Kanie, J 2, 2-3), gdzie słowa „impra”, a nawet „wino” zdają się sugerować, że Ewangelia opisuje spotkania („,imprezy") typowe dla współczesnych użytkowników języka środowiskowego.

W tego rodzaju próbach przenoszenia tekstu biblijnego na grunt regionalnych i środowiskowych odmian polszczyzny na szczególne niebezpieczeństwo narażone są stałe zespolenia wyrazowe (frazeologizmy), będące nierzadko świadectwem bogatej aforystyki ludów Wschodu. Część z tych form trafiła na karty biblijne już w postaciach i znaczeniach utrwalonych. W drodze wiernych tłumaczeń z polszczyzną biblijną na trwałe zrosły się więc takie frazy i zwroty, jak np. „lekarzu, ulecz samego siebie” (Łk 4, 23), „wierzgać przeciw ościeniowi” (Dz 26, 14) i in. Jakakolwiek próba oddania tych jednostek w gwarowych czy też slangowych postaciach równa się ostatecznie ich unicestwieniu.

5. Tego typu zabiegi „translatorskie” nie służą naszym zdaniem udostępnianiu Pisma Świętego, ale narażają jego treść na językową trywializację, a na płaszczyźnie doświadczenia religijnego na bezrefleksyjne mieszanie sacrum z profanum. Nie mają też, niestety, wartości literackiej, która mogłaby być argumentem na ich „obronę”.

Pomysły wątpliwej jakości merytorycznej i nieumiejętne wykonanie szkodzą tekstom uznawanym przez chrześcijan za święte. Szkodzą też dialektowi czy gwarze. Na niewiele zda się również szermowanie hasłem inkulturacji, jeśli przedstawiane teksty będą niedopracowane, a z lokalnej bądź środowiskowej kultury brać będą w sposób nieprzemyślany tylko pewne powierzchowne elementy. Takie zabiegi nie przysłużą się ani ewangelizacji, ani szacunkowi dla regionalizmów i gwar ${ }^{6}$.

${ }^{5}$ Impra - to samo co impreza, spotkanie towarzyskie w mieszkaniu, lokalu połączone z piciem alkoholu - prywatka; także dyskoteka, zabawa, koncert itp. - por. M. Czeszewski, Słownik slangu młodzieżowego, Piła 2001, s. 90.

${ }^{6}$ Do którego wzywa ustawa z dnia 7 października 1999 r. o języku polskim, art. 3 ust. 1 pkt 4. 
6. Należy również poruszyć aspekt prawny. Zgodnie z obowiązującymi przepisami prawo tłumaczenia i wydawania ksiąg liturgicznych, w tym lekcjonarzy i ewangeliarzy, a także dopuszczania ich do liturgii przysługuje konferencji episkopatu (por. Kodeks prawa kanonicznego, kan. 838, § 3). Tymczasem w niektórych parafiach Podhala korzysta się podczas mszy świętej z amatorskiego, pośpiesznego i nieposiadającego imprimatur „przekładu” Ewangelii „na gwarę górali skalnopodhalańskich z Zakopanego”.

Bogactwo i wielowiekowy dorobek polskiej translatoryki biblijnej mierzy się zarówno pomnikowymi dokonaniami teologów-egzegetów, jak też wielorakimi formami indywidualnych prób spotkania ze słowem natchnionym, w tym również jego literackich adaptacji w konkretnym języku autora i epoki. Naszą intencją nie jest więc krępowanie inicjatyw zmierzających do przybliżania jego tajemnicy i piękna w języku odpowiadającym także wyzwaniom i potrzebom współczesności. Ranga i powaga ksiąg biblijnych wymaga jednak, aby inicjatywy te były dokonywane na poziomie spełniającym wymogi teologiczne, translacyjne oraz stylistyczne. Naszym zdaniem nadzieję na to dają nie tyle indywidualne próby nawet doświadczonych tłumaczy, lecz zespolone wysiłki zarówno biblistów, jak i filologów.

DR ARTUR CZESAK, dialektolog

(Polska Akademia Nauk Instytut Języka Polskiego)

PROF. DR HAB. JÓZEF KĄŚ, dialektolog (Uniwersytet Jagielloński Katedra Historii Języka i Dialektologii)

DR HAB. STANISŁAW KOZIARA, językoznawca (prof. Akademii Pedagogicznej w Krakowie Instytut Filologii Polskiej)

DR HAB. RENATA PRZYBYLSKA, językoznawca (prof. Uniwersytetu Jagiellońskiego Katedra Historii Języka i Dialektologii)

KS. DR HAB. WIESŁAW PRZYCZYNA CSSR, teolog (Papieska Akademia Teologiczna w Krakowie Instytut Liturgiczny)

PROF. DR HAB. HELENA SYNOWIEC, dialektolog (Uniwersytet Ślaski Katedra Dydaktyki Języka i Literatury Polskiej)

O. DR PIOTR WŁODYGA OSB, biblista (Papieska Akademia Teologiczna w Krakowie Specjalizacja Biblijna)

O. DR RYSZARD WRÓBEL OFMConv., teolog (Papieska Akademia Teologiczna w Krakowie)

${ }^{7}$ „Ewangelia w gwarze zakopiańskich górali czytana jest w kościołach na Krzeptówkach, na Cyrhli, w Kościelisku...” (M. Dvořák, Wgwarze sercu bliższe, „Gazeta Wyborcza. Kraków” z 3 stycznia 2005, s. 1). 